ANUVA Volume 2 (3): 317-324, 2018

Copyright (C2018, ISSN: 2598-3040 online

Available Online at: http://ejournal.undip.ac.id/index.php/anuva

\title{
Thematic Analysis sebagai Metode Menganalisa Data untuk Penelitian Kualitatif
}

\author{
Heriyanto*) $^{*}$ \\ ${ }^{I}$ Program Studi Ilmu Perpustakaan, Fakultas Ilmu Budaya, Universitas Diponegoro, \\ Jl. Prof. Soedarto, SH, Kampus Undip Tembalang, Semarang, Indonesia \\ ${ }^{*}$ Korespondensi: heriyanto@ live.undip.ac.id
}

\begin{abstract}
The title of this article is Thematic Analysis as a data analysis method for qualitative study. It aims to explore how it can be used for analysing qualitative data. This paper is also describing how it can be implemented in a qualitative study. Thematic Analysis is a method for identifying and interpreting meaning within qualitative data. It has been used for number of qualitative studies, especially for Social Science research, including library and information science research. In this paper, thematic analysis is implemented in a qualitative study that aims to explore people's experience of open access as part of their information literacy. The study has identified four themes within the data, they are Understanding Open Access, Institutional Repository, Publishing and Dissemination, and Finding Information. Further to that, the realtionships between each theme were also discovered.
\end{abstract}

Keywords: thematic analysis; data analysis method; qualitative research; library and information science; library and information science research

\begin{abstract}
Abstrak
Artikel ini berjudul Thematic Analysis sebagai Metode untuk menganalisa Data untuk Penelitian Kualitatif. Tulisan ini bertujuan untuk mendeskripsikan tentang apakah itu thematic analysis sekaligus mengilustrasikan bagaimana metode ini digunakan pada salah satu penelitian kualitatif. Thematic analysis Thematic analysis merupakan salah satu cara untuk menganalisa data dengan tujuan untuk mengidentifikasi pola dan menemukan tema melalui data yang telah dikumpulkan oleh peneliti. Thematic analysis telah digunakan pada beberapa penelitian ilmu-ilmu sosial, termasuk ilmu perpustakaan dan informasi. Artikel ini juga menunjukkan bagaimana thematic analisis ini secara teknis diimplementasikan dalam menganalisa sebuah penelitian yang bertujuan untuk memahami literasi informasi peneliti saat menggunakan open access. Penelitian tersebut menemukan empat tema, yaitu pemahaman tentang open access, institutional repository, publikasi dan diseminasi, dan penelusuran informasi. Selain itu, penelitian ini juga berhasil menemukan hubungan antar masing-masing tema.
\end{abstract}

Kata kunci: thematic analysis; teknik analisa data; penelitian kualitatif; ilmu perpustakaan dan informasi; penelitian ilmu perpustakaan dan informasi

\section{Pendahuluan}

Penelitian kualitatif merupakan sebuah penelitian yang melibatkan proses yang cukup komplek. Hal ini disebabkan sebuah penelitian yang telah memilih untuk dilakukan secara kualitatif memiliki karakteristik sebuah penelitian yang bertujuan untuk mengeksplorasi dan menceritakan pengalaman seseorang yang terlibat dalam sebuah kejadian. Oleh sebab itu diperlukan sebuah teknik untuk menganalisa data-data kualitatif yang telah dikumpulkan oleh peneliti guna mendapatkan jawaban-jawaban sesuai dengan rumusan masalah yang ada.

Ada beberapa Teknik menganalisa data yang lazim digunakan dalam penelitian kualitatif. Misalnya content analysis, discourse analysis, dan thematic analysis. Tulisan ini mengupas satu metode saja yang digunakan untuk menganalisa data, yaitu thematic analysis. 
Dalam menuliskan metode ini, penulis mengilustrasikan pengalaman yang telah penulis lakukan selama melakukan penelitiannya. Penelitian tersebut dilakukan secara kualitatif yang bertujuan untuk memahami literasi informasi peneliti Australia saat berinteraksi dengan open access.

\section{Thematic Analysis}

Thematic analysis merupakan salah satu cara untuk menganalisa data dengan tujuan untuk mengidentifikasi pola atau untuk menemukan tema melalui data yang telah dikumpulkan oleh peneliti (Braun \& Clarke, 2006). Cara ini merupakan metode yang sangat efektif apabila sebuah penelitian bermaksud untuk mengupas secara rinci data-data kualitatif yang mereka miliki guna menemukan keterkaitan pola-pola dalam sebuah fenomena dan menjelaskan sejauhmana sebuah fenomena terjadi melalui kacamata peneliti (Fereday \& Muir-Cochrane, 2006). Bahkan Holoway \& Todres (2003) mengatakan bahwa thematic analysis ini merupakan dasar atau pondasi untuk kepentingan menganalisa dalam penelitian kualitatif.

Ada beberapa metode yang dapat digunakan dalam penelitian kualitatif, dan thematic ini analysis ini sangat penting untuk dipelajari karena dianggap sebagai core skills atau pengetahuan dasar untuk melakukan analisa dalam penelitian-penelitian kualitatif. Bahkan lebih lanjut dapat dikatakan bahwa pengidentifikasian tema yang mejadi ciri khas thematic analysis ini merupakan salah satu generic skills bagi sebagian besar metode analisa kualitatif (Holloway \& Todres, 2003).

\section{Tahapan melakukan thematic analysis.}

Beberapa tahapan dalam melakukan analisa data ini kurang lebih sama dengan teknik analisa kualitatif yang lain, misalnya adalah tahapan paling awal yang dilakukan, yaitu memahami data yang telah diperoleh. Dalam thematic analysis peneliti perlu untuk meluangkan waktunya untuk 'mengenal lebih dekat' data yang mereka telah peroleh sebelum melakukan tahapan-tahapan berikutnya. Untuk lebih rinci bagaimana teknis melakukan analisa data dengan menggunakan metode thematic analysis, berikut ini disampaikan tahapan-tahapannya.

\section{A. Memahami data}

Mendapatkan data yang diinginkan bukan berarti peneliti memahami fenomena yang sedang diteliti. Karena penelitian kualitatif bertujuan untuk mengupas secara mendalam apa yang terjadi dari sebuah peristiwa melalui perspektif partisipan, maka rekaman dan transkrip wawancara ibaratnya adalah 'harta karun' peneliti yang perlu untuk dieksplorasi maknanya lebih dalam. Disini peneliti perlu untuk memahami dan menyatu dengan data kualitatif yang diperolehnya. Dan tidak ada cara lain yang lebih efektif untuk lebih menyatu dengan data selain membaca dan membaca kembali transkrip wawancara dan bahkan mendengarkan kembali rekaman wawancara atau menonton lagi rekaman video yang sudah dibuat selama proses pengumpulan data. Rekaman wawancara bisa menjadi sumber penting dalam proses analisa data karena peneliti bisa mendapatkan informasi-informasi atau insights yang melalui percakapan-percakapn 
yang dilakukannya bersama partisipan. Maka dari itu peneliti sempatkan waktu paling tidak satu kali untuk mendengarkannya kembali. Kegiatan ini menjadi lebih penting lagi apabila yang membuat transkrip wawancaranya bukan peneliti sendiri.

Satu hal lagi yang juga penting dilakukan diproses ini adalah dengan data ini adalah dengan membuat catatan pribadi selama membaca transkrip atau saat sedang mendengarkan rekaman wawancara. Penulisan catatan ini bisa dilakukan sesuai dengan minat masing-masing peneliti. Misalnya catatan bisa ditulis dibuku tulis khusus untuk kepentingan penelitian, atau langsung ditulis ditranskrip wawancara. Catatan ini dilakukan untuk menandai poin-poin penting yang bisa jadi ditemui didalam transkrip atau rekaman. Yaitu hal-hal yang sekiranya berpotensi menarik perhatian peneliti saat mulai menganalisa data ditahapan selanjutnya, pengcodingan data misalnya.

Selain itu, penulisan catatan ini juga berfungsi membantu peneliti untuk membaca data sebagai data. Artinya, peneliti tidak hanya memahami data dari apa yang kelihatan dipermukaan, tapi sejauhmana peneliti bisa menemukan makna yang terkandung didalam data tersebut. Oleh karena itu, ditahapan ini peneliti diharapkan untuk bisa membaca secara aktif, kritis, dan mulai memikirkan apa saja kira-kira makna yang tbisa ditemukan didalam data yang ia baca.

Tujuan utama tahapan pertama ini adalah supaya peneliti mulai merasa memahami isi data yang ia peroleh, dan mulai menemukan beberapa hal didalam data yang terkait dengan pertanyaan penelitiannya. Untuk mencapai hal itu, maka sangat wajar apabila peneliti mau untuk membaca transkrip wawancaranya minimal sekali, dua kali bahkan tiga kali sekalipun sampai peneliti benar-benar merasa paham dan 'dekat' dengan data. Plus, digabung dengan catatan-catatan yang dibuat selama membaca akan merupakan satu hal vital sifatnya observatif untuk menelusuri kedalaman data yang ia baca.

Membuat catatan disini bukan berarti peneliti mulai meng-coding datanya. Namun catatan-catatan itu bisa berupa coretan-coretan atau highlight dilembaran transkrip wawancara, atau bisa juga seperti catatan kecil buku diary yang umumnya hanya bisa dipahami oleh peneliti sendiri. Karena memang tujuan catatan ini adalah selain sebagai menggarisbawahi beberapa hal yang berpotensi untuk di coding nantinya, juga sebagai reminder bagi peneliti untuk mengamati data yang ia miliki hingga tiap baris transkrip wawancara yang ia miliki.

\section{B. Menyusun Kode}

Tahapan kedua dalam proses thematic analysis adalah mulai meng-coding. Meng-coding ini bisa diibaratkan pustakawan yang sedang menentukan subyek dari judul buku. Atau seperti pembaca yang berusaha menemukan pikiran utama sebuah paragraph.

Kode bisa juga dianggap sebagai label, atau fitur yang terdapat dalam data yang terkait dengan pertanyaan penelitian. Dalam hal ini peneliti lah yang menentukan data mana saja dalam transkrip wawancaranya yang perlu dikode. Bagi peneliti yang baru melakukan coding, kemungkinan besar ia akan memberikan kode semua data dalam transkrip. Ini tidak apa-apa dilakukan, karena nanti ditahapan 
berikutnya, peneliti akan meninjau kembali semua kode yang ia buat dan akan mengevaluasi kode mana yang relavan dengan penelitiannya dan kode mana yang tidak relevan.

Kode dapat dibuat baik secara semantik, artinya menggambarkan secara langsung apa yang tampak dari data. Peneliti menuliskan kode sesuai dengan apa yang tampak di permukaan. Ini biasanya dilakukan peneliti dengan cara menuliskan kode sesuai dengan kata-kata yang digunakan oleh partisipan. Metode peng-kode-an ini disebut juga sebagai in vivo kode.

Selain itu kode juga dapat dibuat dengan menuliskan makna yang terkandung didalam data. Disini penulis mencoba menginerpretasikan apa yang tersembunyi dibalik kata-kata partisipan.

\begin{tabular}{|c|c|}
\hline \multicolumn{2}{|c|}{$\begin{array}{l}\text { Tabel } 1 \\
\text { Contoh transkip dan kode-nya }\end{array}$} \\
\hline $\begin{array}{l}\text { Transkrip } \\
\text { Int: pernah mencari informasi lewat repository? }\end{array}$ & Kode \\
\hline $\begin{array}{l}\text { Bob: Jarang sekali. Repository bagi saya hanyalah } \\
\text { sebuah tempat untuk mencari informasi yang } \\
\text { sebenarnya sudah pernah dipublikasikan ditempat } \\
\text { lain. } \\
\text { Int: apakah anda pernah menerbitkan artikel secara } \\
\text { open access? }\end{array}$ & $\begin{array}{l}\text { Motivasi untuk tidak menggunakan } \\
\text { repository }\end{array}$ \\
\hline $\begin{array}{l}\text { Bob: Alasan filosofis saja sebenarnya. Karena } \\
\text { penelitian yang kami lakukan didanai menggunakan } \\
\text { dana masyarakat jadi sudah seharusnya hasil } \\
\text { penelitian kami terbuka buat siapa saja }\end{array}$ & Motivasi menerbitkan open access \\
\hline $\begin{array}{l}\text { Bob: Selama memungkinkan saya akan memilih untuk } \\
\text { menerbitkan tulisan saya di jurnal open access }\end{array}$ & Komitmen ke open access \\
\hline $\begin{array}{l}\text { Bob: tetapi pada kenyataannya saya tidak selalu bisa } \\
\text { menerbitkan di open access. Untuk tulisan yang } \\
\text { terakhir, pembimbing saya meminta untuk } \\
\text { menerbitkan dijurnal tertentu, dan itu bukan jurnal } \\
\text { open access }\end{array}$ & $\begin{array}{l}\text { Hambatan dalam memilih jurnal } \\
\text { open acccess }\end{array}$ \\
\hline
\end{tabular}

Tabel 1. Contoh transkrip dan kode 
Kode harus diusahakan ditulis sejelas mungkin sehingga nantinya melalui kode ini peneliti jadi lebih paham akan makna dari setiap pernyataan partisipan. Oleh karena itu kode tidak harus deskriptif atau panjang lebar. Namun merupakan perpaduan dari deskriptif dan interpretatif.

Ada kecenderungan peneliti pemula akan menuliskan kode yang deskriptif, namun ini wajar terjadi karena peneliti mungkin mencoba untuk menuliskan fenomena atau persepsi partisipan. Dan ini sah-sah saja dilakukan. Pada akhirnya nanti kemampuan meng-coding akan dikuasai peneliti seriring dengan seringnya mereka melakukan pengkodean.

Namun juga ini bukan berarti kode interpretatif lebih baik daripada deskriptif, tetapi membuat kode interpretatif kode biasanya lebih sulit daripada yang deskriptif karena harus bisa melihat makna yang lebih dalam dari data yag ada. Selain itu, yang lebih penting lagi adalah sejauhmana relevansi kode yang diciptakan. Relevansi disini berarti kode harus bisa digunakan untuk menjawab rumusan masalah penelitian.

Apabila pengkodean transkrip pertama bahkan sampai transkrip ketiga selesai, peneliti sangat disarankan untuk membaca kembali data yang ia miliki. Harapannya apabila peneliti mulai mengkode transkrip berikutnya peneliti dapat menentukan apakah ia akan menggunakan kode yang telah ia buat atau perlu membuat kode baru.

Tahapan ini baru bisa dibilang selesai ketika semua data telah selesai dibuatkan kodenya dan semua kode yang memiliki makna atau arti yang sama dijadikan dalam satu group atau kelompok. Peneliti kemudian memberi nama kelompok ini sesuai dengan isi (kode) didalam group tersebut. Tabel 2 menunjukkan contoh bagaimana kode yang memiliki kemiripan dikelompokan menjadi satu dan diberi nama sesuai dengan makna yang terkandung dalam kode. Kolom terakhir ditabel 2 menunjukkan deskripsi singkat masing-masing group.

\begin{tabular}{|l|l|l|}
\hline \multicolumn{1}{|c|}{ Kelompok } & \multicolumn{1}{|c|}{ Kode } & \multicolumn{1}{|c|}{ Deskripsi } \\
\hline Komitmen terhadap Open Access & $\begin{array}{l}\text { Laporan penelitian harus bisa diakses secara terbuka } \\
\text { Dapat diakses oleh masyarakat umum } \\
\text { Menghilangkan hambatan dalam pendistribusian hasil } \\
\text { penelitian } \\
\text { Manfaat open access bagi negara2 miskin } \\
\text { Merasa menyesal menerbitkan dijurnal non-open access }\end{array}$ & $\begin{array}{l}\text { Pernyataan partisipan yang } \\
\text { komitmen untuk selalu } \\
\text { bentuk tanggung jawabnya kepada } \\
\text { masyarakat luas }\end{array}$ \\
\hline Mendefinisikan Open Access & $\begin{array}{l}\text { Free publications } \\
\text { Berbagai macam dan jenis open access } \\
\text { Siap didownload } \\
\text { Mudah dalam hal akses } \\
\text { Free scientific publication }\end{array}$ & $\begin{array}{l}\text { Pemahaman para partisipan } \\
\text { mengenai apa itu open access }\end{array}$ \\
\hline
\end{tabular}

Tabel 2. Pengelompokkan kode sesuai kesamaan makna 


\section{Mencari Tema}

Ditahapan ini peneliti mulai berpindah perhatian dari yang semula mencari kode sekarang berganti menjadi mencari tema. Seperti yang direkomendasikan oleh Braun \& Clarke (2006), tahap ketiga dalam thematic analysis adalah mencari tema, tema yang sesuai dengan tujuan penelitian. Tema ini menggambarkan sesuatu yang penting yang ada di data terkait dengan rumusan masalah penelitian. Lebih lanjut disampaikan oleh Boyatzis (1998), tema ini menggambarkan pola dari fenomena yang diteliti.

Meski dikatakan mencari tema, namun mencari disini bukan berarti ibarat seorang arkeolog yang menggali tanah untuk menemukan tema yang tersembunyi dibalik data. Tetapi lebih seperti seorang seniman yang menentukan bagaimana ia akan memahat batu yang ia miliki. Batu ini diibaratkan data, dan tema diiibaratkan karya seni hasil pahatannya. Penelitilah yang menentukan tema apa yang akan muncul sesuai dengan data yang ia miliki. Ibarat pematung yang punya kebebasan dalam menentukan wujud dan bentuk patungnya, peneliti juga memiliki kebebasan dalam menginterpretasi data untuk memunclkan tematema tadi. Konsekwensinya, hal ini menunjukkan betapa bervariasinya hasil yang akan didapatkan sesuai dengan kreatifitas seniman, atau sesuai interpretasi peneliti.

Sebagai contoh, ditahapan ini yang saya lakukan adalah meninjau kembali semua kode dan kelompok yang sudah dibentuk. Mengecek kembali semua kode ini perlu dilakukan untuk memastikan bahwa kode didalam masing-masing kelompok mempunyai makna yang sama. Misalnya didalam penelitian saya ada kode yang berbunyi Komitmen terhadap open access, dan ada satu kode yang berbunyi Motivasi memilih open access. Setelah saya melihat transkrip wawancara kembali, saya menemukan bahwa dua kode ini sama-sama menunjukkan bahwa partisipan memiliki kemauan dalam memilih jurnal open access sebagai tempat publikasi artikel mereka. Dari sini saya memutuskan bahwa dua kode ini memiliki memiliki kemiripan, yaitu sama-sama memilih open access sebagai tempat publikasi. Saya lalu memutuskan dua kode tersebut saya masukkan dalam satu kelompok, dimana kelompok itu saya beri nama Pemilihan Tempat untuk Publikasi.

Dalam menentukan nama kelompok, sekali lagi kita perlu berpedoman kepada pertanyaan penelitian sehingga nama-nama kelompok senantiasa konsisten dan relevan dengan fenomena yang sedang diteliti. Pertanyaan penelitian kami adalah "bagaimana pengalaman peneliti saat menggunakan open access terkait dengan literasi informasi mereka?"

Oleh karena itu, kode dan nama kelompok yang dibuat sesuai dengan pertanyaan penelitian diatas. Pun, pengecekan kembali semua kode dan kelompok dilakukan untuk memastikan semua kode dan kelompok menjawab pertanyaan penelitian.

Langkah pertama dalam menentukan tema adalah dengan menentukan tema tentatif terlebih dahulu. Disebut tentatif karena tema-tema yang nantinya akan dibuat merupakan tema awal hasil analisa dan ada kemungkinan berubah sesuai dengan peninjauan yang dilakukan terhadap tema-tema tentatif tersebut.

Bagaimana cara menentukan tema tentatif? Tema tentatif ditentukan berdasarkan hasil observasi peneliti terhadap kode dan kelompok yang memiliki kesamaan ataupun perbedaan makna. Kelompok- 
kelompok yang memiliki kesamaan makna dikumpulkan menjadi satu kelompok menjadi tema tentatif. Selama melakukan tahapan ini kami selalu melihat kembali transkrip-transkrip wawancara untuk memastikan bahwa data yang tertulis disana konsisten dengan tema tentatif yang dibuat. Masing-masing tema tentatif ini lalu kemudian dibandingkan dengan tema tentatif yang lain untuk mengidentifikasi apakah mereka memiliki kesamaan, atau ada perbedaan, bahkan juga untuk menemukan keterkaitan antara tema yang satu dengan tema yang lain.

Ketika tema tentatif selesai disusun, masing-masing tema dikalkulasi kembali berdasarkan signifikansinya, keterkaitannya dengan pertanyaan penelitian, dan kekhasan masing-masing dalam proses dijadikan dalam satu tema. Untuk penelitian kami, tema yang kami temukan adalah sebagai berikut,

1. Pemahaman tentang open access

2. Institutional repository

3. Publikasi dan diseminasi

4. Penelusuran informasi

Deskripsi singkat masing-masing tema kami dijelaskan sebagai berikut:

Tema Pemahaman tentang Open Access menjelaskan tentang pemahaman partisipan tentang open access dan sejauhmana open access ini memberikan manfaat bagi mereka. Lebih jauh, tema ini mengarah kepada bagaimana partisipan memahami apa itu open access, termasuk diantaranya bagaimana mengakses artikel dan jurnal-jurnal open access, serta hal terkait aspek finansial terkait menerbitkan artikel di jurnal open access. Semua pengetahuan dan pengalaman partisipan ini merupakan aspek penting mereka terkait dengan literasi informasi yang dimiliki partisipan.

Tema kedua, yaitu Institutional Repository, menjelaskan pemahaman partisipan mengenai open access khususnya saat mereka menggunakan institutional repository. Melalui tema ini dapat dipahami literasi informasi para partisipan yang terkait dengan interaksi mereka dengan institutional repository, khususnya terkait dengan aktivitas penelitian mereka, misalnya menginisiasi untuk melakukan kolaborasi penelitian dengan peneliti lain dimana mereka mengidentifikasi biodata peneliti lain dilingkungan perguruan tinggi mereka melalui institutional repository, dan juga serba-serbi pengalaman dan pendapat mereka dalam meng-upload hasil publikasi kedalam repository. Disini para partisipan melaporkan bagaimana institutional repository banyak berkontribusi dalam mendistribusikan hasil penelitian mereka sekaligus dalam membangun profil partisipan sebagai seorang peneliti.

Tema ketiga yaitu Publikasi dan Diseminasi. Tema ini menggambarkan pengalaman partisipan dalam menggunakan open access sebagai bagian dari literasi informasi mereka terkait dengan publikasi dan diseminasi karya ilmiah para partisipan. Melalui tema ini kami dapat mengetahui minat para partisipan saat tiba waktunya untuk memilih salah satu media untuk mempublikasikan hasil penelitian mereka. Selain itu disini para partisipan juga berbicara sejauhmana open access dimanfaatkan untuk mendistribusikan artikelartikel penelitian mereka. Tema Publikasi dan Diseminasi dalam penelitian kami menceritakan literasi 
informasi para partisipan terkait dengan kegiatan mereka dalam mempublikasikan dan menyebarkan karya ilmiah mereka.

Tema yang terakhir yaitu Penelusuran Informasi mengilustrasikan pengalaman para partisipan dalam menemukan informasi melalui sumber-sumber informasi berbasis open access. Sebagai seorang peneliti, para partisipan dalam penelitian ini mencari, menemukan, mengevaluasi, dan menggunakan informasi untuk penelitian mereka. Meskipun mereka tidak secara khusus bertujuan mencari informasi yang berbasis open access, namun pada kenyataannya mereka sering berinteraksi dengan sumber-sumber informasi open access. Maka melalui tema ini tergambarkan literasi informasi para partisipan saat menemukan informasi open access.

\section{Simpulan}

Thematic analysis merupakan salah satu cara yang dapat digunakan untuk menganalisa data-data kualitatif, misalnya data yang diperoleh dari wawancara mendalam atau semi-structured interview seperti yang dilakukan dalam penelitian ini. Teknik analisa data ini sangat tepat dilakukan apabila sebuah penelitian bertujuan untuk mengeksplorasi apa yang sesungguhnya terjadi dalam sebuah fenomena. Secara khusus thematic analysis digunakan untuk mengidentifikasi pola dalam sebuah peristiwa yang menjadi obyek penelitian. Thematic analysis banyak digunakan dalam ilmu sosial (Braun \& Clarke, 2006) serta kajian-kajian ilmu perpustakaan dan informasi, misalnya penelitian yang dilakukan oleh Yates \& Partridge (2015) dan juga penelitian yang dilakukan oleh Heriyanto, Partridge \& Davis (2018).

\section{Daftar Pustaka}

Boyatzis, R.E. (1998). Transforming qualitative information: Thematic analysis and code development. Thousand Oaks: Sage.

Braun, V., \& Clarke, V. (2006). Using thematic analysis in psychology. Qualitative Research in Psychology, 3(2), p.77-101. Retrieved from http://eprints.uwe.ac.uk/11735/2/thematic_analysis_revised_-_final.pdf

Fereday, J., \& Muir-Cochrane, E. (2006). Demonstrating rigor using thematic analysis: A hybrid approach of inductive and deductive coding and theme development. International Journal of Qualitative Methods, 5(1), 80-92.

Heriyanto, Partridge, H., \& Davis, K. (2018). Understanding how Australian researchers experience open access as part of their information literacy. Retrieved from https://eprints.qut.edu.au/117651/

Holloway, I., \& Todres, L. (2003). The status of method: flexibility, consistency and coherence. Qualitative Research, 3(3), 345-357.

Yates, C. \& Partridge, H. (2015). Citizens and social media in times of natural disaster: Exploring information experience. Information Research, 20(1), paper 659. 